\title{
PENGARUH PUPUK KASCING DAN HERBAFARM TERHADAP PERTUMBUHAN DAN HASIL TANAMAN KUBIS (Brassica oleraceae var. Capitata L.)
}

\section{Effects of Kascing and Herbafarm Fertilizers on Growth and Production of Cabbage (Brassica oleraceae var. Capitata L.)}

\author{
Miftahul Hidayah, Herman, dan Fathurrahman \\ Program Studi Agroteknologi, Fakultas Pertanian Universitas Islam Riau \\ Email : fathur@agr.uir.ac.id \\ [Diterima: Januari 2020; April 2020]
}

\begin{abstract}
This study was conducted to examine the effect of interaction between Kascing and Herbafarm fertilizers on cabbage growth and yield. This study used a Factorial Completely Randomized Design consisting of 2 factors. The first factor was the application of kascing fertilizer (K) which consisted of 4 levels. The second factor was fertilization of Herbafarm $(\mathrm{H})$ which consisted of 4 levels, so that this experiment had 16 treatment combinations. The parameters observed were the age of crop formation (days), crop diameter (cm), fresh weight of the crop (grams), and the number of leaves that not formed a crop (strands). The results showed that interaction of kascing fertilizer and Herbafarm was significantly affected on the crop diameter and fresh weight of cabbage crop heads. The best treatment was $1.8 \mathrm{~kg}$ of kascing fertilizer per plot and $75 \mathrm{ml}$ of Herbafarm concentration per plant (K3H3). The main significant effect of kascing was found on the age of crop formation, crop diameter, fresh crop weight and number of leaves that not formed crop. The main significant effect of Herbafarm was found on the age of crop formation, crop diameter, fresh crop weight and number of leaves that not formed crop. The best treatment was $75 \mathrm{ml}$ herbafarm per plant.
\end{abstract}

Keywords: Kascing and Herbafarm fertilizers, Growth, Yield, Cabbage

\begin{abstract}
Tujuan penelitian ini adalah untuk mengetahui pengaruh interaksi pupuk Kascing dan Herbafarm terhadap pertumbuhan dan hasil kubis. Penelitian ini menggunakan Rancangan Acak Lengkap Faktorial yang terdiri dari 2 faktor. Faktor pertama adalah pemberian pupuk kascing (K) yang terdiri dari 4 taraf. Faktor kedua yaitu pemberian Herbafarm $(\mathrm{H})$ yang terdiri dari 4 taraf, sehingga percobaan ini menjadi 16 kombinasi perlakuan. Parameter yang diamati adalah umur terbentuknya krop (hari), diameter krop $(\mathrm{cm})$, berat segar krop (gram), dan jumlah daun yang tidak membentuk krop (helai). Hasil penelitian menunjukan bahwa interaksi pupuk kascing dan Herbafarm berpengaruh nyata terhadap diameter krop dan berat segar krop tanaman kubis. Perlakuan terbaik adalah pupuk kascing dosis $1,8 \mathrm{~kg}$ per plot dan Herbafarm konsentrasi $75 \mathrm{ml}$ per tanaman $(\mathrm{K} 3 \mathrm{H} 3)$. Pengaruh utama kascing berpengaruh nyata terhadap umur terbentuknya krop, diameter krop, berat segar krop dan jumlah daun yang tidak membentuk krop. Pengaruh utama Herbafarm berpengaruh nyata terhadap umur terbentuknya krop, diameter krop, berat segar krop dan jumlah daun yang tidak membentuk krop. Perlakuan terbaik herbafarm $75 \mathrm{ml}$ per tanaman.
\end{abstract}

Kata kunci: Pupuk cascing dan Herbafarm, pertumbuhan, produksi, kubis

\section{PENDAHULUAN}

Kubis (Brassica oleraceae var. capitata L.) atau yang lebih dikenal dengan kol merupakan tanaman semusim atau dua musim yang termasuk dalam familli Brassicaceae. Bentuk daunnya bundar, daun ini tersusun sangat rapat membentuk bulatan atau bulatan pipih yang disebut krop, dan lebar seperti kipas. Kubis mengandung protein, vitamin A, vitamin $\mathrm{C}$, vitamin $\mathrm{B} 1$, vitamin $\mathrm{B} 2$, dan niacin. Kandungan protein pada kubis putih lebih rendah dibandingkan dengan kubis bunga, tetapi kandungan vitamin A-nya lebih tinggi dibandingkan dengan kubis bunga (Cahyono, 2005).

Tanaman kubis dikenal sebagai tanaman dataran tinggi yang tumbuh pada suhu berkisar $15^{\circ} \mathrm{C}-20^{\circ} \mathrm{C}$, dapat tumbuh optimal pada 
ketinggian 200-3.000 m dari permukaan laut (dpl) varietas dataran tinggi, dapat tumbuh baik pada ketinggian $1.000-3.000 \mathrm{~m} \mathrm{dpl}$ (Sunarjono, 2014).

Ketersediaan sayur bagi masyarakat Pekanbaru masih belum mencukupi. Saat ini Riau masih kekurangan produksi sayuran sekitar 269.505 ton $(87,6 \%)$ dari total kebutuhan sebesar 325.213 ton. Hal ini terjadi karena produktivitas lahan untuk budidaya tanaman sayuran serta cuaca yang tidak menentu di wilayah Pekanbaru sehingga produksi sayuran berkurang.

Peningkatan produksi tanaman dapat dilakukan dengan penambahan pupuk organik. Penggunaan pupuk organik dapat memperbaiki struktur, sifat fisik, kimia dan biologi tanah serta dapat meningkatkan produksi pada tanaman. Penggunaan pupuk organik tersebut diantaranya adalah pupuk Kascing dan pupuk cair Herbafarm. Upaya ini dapat mendukung sistem pertanian berkelanjutan dimana tanpa penggunaan pupuk anorganik dan meningkatkan penggunaan pupuk organik. Meskipun kandungan pada pupuk organik lebih sedikit dibandingkan oleh pupuk anorganik.

Menurut Lingga (2013), tanaman kubis tumbuh baik dengan tanah yang berstruktur gembur. Tanah yang gembur akan terdapat pori-pori yang dapat diisi oleh air tanah dan udara yang sangat penting untuk pertumbuhan akar tanaman. Struktur tanah yang remah adalah struktur tanah yang dikehendaki karena mempunyai keuntungan udara dan air berjalan lancar dan temperatur stabil. Keadaan ini akan memacu pertumbuhan jasad renik yang diperlukan untuk proses pelapukan bahan organik.

Karena hal-hal tersebut agar diperoleh hasil pemupukan yang efisien dan tidak merusak akar tanaman maka harus diketahui sifat, macam dan jenis pupuk serta cara pemberian pupuk yang tepat. Selain itu, pemberian pupuk organik akan menambah unsur hara yang dibutuhkan dalam pertumbuhan tanaman (Musnawar, 2006).

Pupuk kascing atau bekas kotoran cacing (Fasenya) yang berbentuk serbuk, berwarna kehitam-hitaman yang ukurannya lebih kecil dari partikel-partikel tanah biasa, sehingga lebih cocok untuk pertumbuhan tanaman, mempercepat waktu panen, menggemburkan tanah atau menyuburkan tanah, baik untuk media tanam pembuahan (Mulat, 2003).

Penelitian sawi oleh Kariada dkk., (2004), mendapatkan bahwa pupuk kascing mengakibatkan penampilan tanaman yang segar, lembut, warna bagus, cerah dan mengkilat. Jumlah daun berpengaruh pada berat segar tajuk tanaman. Berat segar tajuk meningkat dengan penggunaan pupuk kascing. Peningkatan berat segar tajuk akibat penambahan dosis pupuk kascing dari 4 hingga 12 ton per ha.

Hasil penelitian Fransiska (2009), pupuk kascing mampu meningkatkan tinggi tanaman, jumlah daun, luas daun dan bobot segar pada tanaman sawi. Sedangkan hasil penelitian Paramita (2009), dengan pemberian 7,5 ton per ha mampu meningkatkan tinggi tanaman, jumlah daun, diameter krop, berat basah bagian atas (krop), dan bawah akar tanaman, berat kering bagian atas (krop) dan bawah akar tanaman pada tanaman selada.

Herbafarm berfungsi sebagai dekomposer, penyedia nutrisi alami, meningkatkan kesuburan tanah melalui perbaikan terhadap kondisi biologis, kimia dan fisik tanah serta meningkatkan imunitas dan adaptasi tanaman terhadap faktor lingkungan yang kurang baik bagi pertumbuhannya (Suriadikarta dkk, 2006), didukung oleh Syafrizal (2014), pupuk Herbafarm meningkatkan pertumbuhan dan produksi tanaman mentimun.

Berdasarkan permasalahan diatas penulis telah melakukan penelitian dengan judul Pengaruh Pupuk Kascing dan Herbafarm Terhadap Pertumbuhan dan Hasil Tanaman Kubis (Brassica oleraceae var. Capitata L.).

\section{BAHAN DAN METODE}

Bahan yang digunakan dalam penelitian ini adalah benih kubis varietas Sehati $F_{1}$, pupuk kascing, Herbafarm, Dithane M-45, Curacorn, MPHP (mulsa plastik hitam perak), polybag $10 \times 6 \mathrm{~cm}$, dan sekam padi. Sedangkan alat yang digunakan dalam penelitian ini adalah: meteran, penggaris, jangka sorong, gunting stek, cangkul, timbangan, seng, kamera dan gunting.

Penelitian ini menggunakan Rancangan Acak Lengkap (RAL) 2 faktorial. Faktor pertama adalah pupuk kascing (K) dengan 4 taraf dan faktor kedua adalah Herbafarm $(\mathrm{H})$ dengan 4 taraf sehingga 
percobaan ini terdiri dari 16 kombinasi perlakuan. Setiap kombinasi perlakuan diulang sebanyak 3 kali, sehingga percobaan ini terdiri dari 48 satuan percobaan, dimana setiap ulangan terdiri dari 4 tanaman dan 2 tanaman dijadikan sampel pengamatan, sehingga total keseluruhan tanaman berjumlah 192 tanaman.

\section{HASIL DAN PEMBAHASAN}

\section{Umur terbentuknya krop (hari)}

Hasil pengamatan terhadap umur terbentuknya krop, setelah dilakukan analisis ragam menunjukkan bahwa secara interaksi perlakuan pupuk kascing dan Herbafarm tidak memberikan pengaruh nyata terhadap umur terbentuknya krop. Namun secara utama kascing dan Herbafarm memberikan pengaruh nyata terhadap umur terbentuknya krop. Rerata umur terbentuknya krop setelah di uji lanjut BNJ pada taraf 5\% dapat dilihat pada Tabel 1.

Berdasarkan data Tabel 1 menunjukkan bahwa secara utama pupuk kascing memberikan pengaruh nyata terhadap umur terbentuknya krop, dimana umur terbentuknya krop tercepat terdapat pada perlakuan kascing sebanyak $1,8 \mathrm{~kg}$ per plot (K3) yaitu 36,00 hst tidak berbeda nyata dengan perlakuan (K2) yaitu 39,00 hst namun berbeda nyata pada perlakuan lainnya.

Tabel 1. Rerata umur terbentuknya krop kubis dengan perlakuan kascing dan Herbafarm (hari).

\begin{tabular}{cccccc}
\hline Dosis Kascing & \multicolumn{3}{c}{ Dosis Herbafarm ml per tanaman } & \multirow{2}{*}{ Rerata } \\
\cline { 2 - 5 } Kg/plot & $\mathrm{H} 0(0)$ & $\mathrm{H} 1(25)$ & $\mathrm{H} 2(50)$ & $\mathrm{H} 3(75)$ & $46,83 \mathrm{~d}$ \\
\hline K0 $(0)$ & 50,00 & 46,67 & 45,33 & 45,33 & $41,58 \mathrm{c}$ \\
K1 $(0,6)$ & 43,33 & 42,33 & 42,00 & 38,67 & $39,00 \mathrm{~b}$ \\
K2 $(1,2)$ & 41,00 & 39,33 & 38,67 & 37,00 & $36,00 \mathrm{a}$ \\
K3 $(1,8)$ & 37,33 & 36,33 & 36,00 & 34,33 & $38,83 \mathrm{a}$ \\
\hline Rerata & $42,92 \mathrm{c}$ & $41,17 \mathrm{~b}$ & $40,50 \mathrm{~b}$ & \\
\hline KK=3,22\% & \multicolumn{5}{c}{ BNJ K dan H=1,46 } \\
\hline
\end{tabular}

Angka - angka pada kolom dan baris yang diikuti oleh huruf kecil yang sama menunjukkan tidak berbeda nyata menurut uji beda nyata $(\mathrm{BNJ})$ pada taraf $5 \%$.

Pengaruh utama pemberian Herbafarm memberikan pengaruh nyata terhadap umur terbentuknya krop dimana umur terbentuknya krop tercepat pada perlakuan $\mathrm{H} 3$ yaitu 38,83 hst namun berbeda nyata pada perlakuan lainnya. Hal ini disebabkan karena herbafarm mengandung unsur-unsur hara makro dan mikro dan juga senyawa organik yang sangat lengkap.

\begin{abstract}
Diameter krop (cm)
Hasil pengamatan terhadap diameter krop pada tanaman kubis setelah dilakukan analisis ragam menunjukkan bahwa baik secara interaksi maupun pengaruh utama perlakuan pupuk kascing dan Herbafarm memberikan pengaruh nyata terhadap diameter krop. Rerata diameter krop setelah di uji lanjut BNJ pada taraf 5\% dapat dilihat pada Tabel 2.
\end{abstract}

Tabel 2. Rerata diameter krop pada tanaman kubis dengan perlakuan pupuk kascing dan Herbafarm $(\mathrm{cm})$

\begin{tabular}{|c|c|c|c|c|c|}
\hline \multirow{2}{*}{$\begin{array}{c}\text { Dosis Kascing } \\
\text { Kg/plot }\end{array}$} & \multicolumn{4}{|c|}{ Dosis Herbafarm ml per tanaman } & \multirow{2}{*}{ Rerata } \\
\hline & H0 (0) & H1 (25) & $\mathrm{H} 2(50)$ & H3 (75) & \\
\hline K0 (0) & $10,50 \mathrm{i}$ & $11,13 \mathrm{hi}$ & $12,37 \mathrm{gh}$ & $12,72 \mathrm{fg}$ & $11,68 \mathrm{c}$ \\
\hline K1 $(0,6)$ & 13,43 efg & 14,47 cde & $15,17 \mathrm{c}$ & $15,67 \mathrm{bc}$ & $14,68 \mathrm{~b}$ \\
\hline $\mathrm{K} 2(1,2)$ & $13,43 \mathrm{efg}$ & $14,87 \mathrm{~cd}$ & $15,27 \mathrm{c}$ & $16,58 \mathrm{ab}$ & $15,04 \mathrm{ab}$ \\
\hline K3 $(1,8)$ & $13,77 \mathrm{def}$ & $14,90 \mathrm{~cd}$ & $15,47 \mathrm{bc}$ & $17,43 \mathrm{a}$ & $15,39 \mathrm{a}$ \\
\hline \multirow[t]{2}{*}{ Rerata } & $12,78 \mathrm{~d}$ & $13,84 \mathrm{c}$ & $14,57 \mathrm{~b}$ & $15,60 \mathrm{a}$ & \\
\hline & $\mathrm{KK}=2,99 \%$ & $\mathrm{BNJ}$ & 0,47 & BNJ KH=1,29 & \\
\hline
\end{tabular}

Angka- angka pada baris dan kolom yang diikuti oleh huruf kecil yang sama tidak berbeda nyata menurut Uji lanjut BNJ pada taraf $5 \%$.

Data Tabel 2 menunjukkan bahwa secara interaksi pemberian pupuk kascing dan herbafarm berpengaruh nyata terhadap diameter krop, dimana perlakuan terbaik terdapat pada perlakuan kascing dan Herbafarm (K3H3) yaitu $17,43 \mathrm{~cm}$, namun tidak berbeda nyata dengan perlakuan $(\mathrm{K} 2 \mathrm{H} 3)$ yaitu $16,58 \mathrm{~cm}$, dan berbeda nyata dengan perlakuan lainnya. Hal ini disebabkan kombinasi perlakuan kascing sebanyak $1,8 \mathrm{~kg}$ plot dan Herbafarm $75 \mathrm{ml}$ per tanaman telah memenuhi unsur hara yang dibutuhkan 
tanaman dalam proses pertumbuhannya. Diameter krop sangat erat hubungannya dengan tinggi tanaman dan jumlah daun, semakin banyak jumlah daun maka diameter krop akan semakin lebar. Selain itu pemanfaatan pupuk sangat berpengaruh untuk menyumbangkan unsur-unsur yang berfungsi untuk pertumbuhan dan pelebaran krop pada tanaman kubis (Prawiranata, et al., 2007).

\section{Berat segar krop (gram)}

Hasil pengamatan terhadap berat segar krop setelah dilakukan analisis ragam menunjukkan bahwa baik secara interaksi maupun pengaruh utama perlakuan pupuk kascing dan Herbafarm memberikan pengaruh nyata terhadap berat segar krop. Rerata berat segar krop tanaman kubis dengan perlakuan pupuk kascing dan Herbafarm dapat dilihat pada Tabel 3.

Tabel 3. Rerata berat segar krop pada tanaman kubis dengan perlakuan kascing dan Herbafarm (gram)

\begin{tabular}{|c|c|c|c|c|c|}
\hline \multirow{2}{*}{$\begin{array}{c}\text { Dosis Kascing } \\
\mathrm{kg} / \mathrm{plot}\end{array}$} & \multicolumn{4}{|c|}{ Dosis Herbafarm ml per tanaman } & \multirow{2}{*}{ Rerata } \\
\hline & H0 (0) & H1 (25) & $\mathrm{H} 2(50)$ & H3 (75) & \\
\hline K0 (0) & $916,67 \mathrm{j}$ & $945,00 \mathrm{i}$ & $963,67 \mathrm{i}$ & $976,00 \mathrm{i}$ & $950,33 \mathrm{~d}$ \\
\hline $\mathrm{K} 1(0,6)$ & $991,67 \mathrm{ghi}$ & $1.075,00 \mathrm{gh}$ & $1.141,67$ efg & $1.174,67$ efg & $1.095,75 \mathrm{c}$ \\
\hline $\mathrm{K} 2(1,2)$ & $1.186,33 \mathrm{def}$ & $1.207,67 \mathrm{cde}$ & $1.228,33 \mathrm{abcd}$ & $1.263,33 \mathrm{abc}$ & $1.221,42 \mathrm{~b}$ \\
\hline $\mathrm{K} 3(1,8)$ & $1.221,67 \mathrm{bcde}$ & $1.253,33 \mathrm{abcd}$ & $1.273,33 \mathrm{ab}$ & $1.310,00 \mathrm{a}$ & $1.264,58 \mathrm{a}$ \\
\hline Rerata & $1.079,08 \mathrm{c}$ & $1.120,25 \mathrm{bc}$ & $1.151,75 \mathrm{ab}$ & $1.181,00 \mathrm{a}$ & \\
\hline
\end{tabular}

Angka- angka pada baris dan kolom yang diikuti oleh huruf kecil yang sama tidak berbeda nyata menurut Uji lanjut $\mathrm{B} N \mathrm{~N}$ pada taraf $5 \%$.

Berdasarkan Tabel 3 menunjukkan bahwa secara interaksi pupuk kascing dan Herbafarm berpengaruh nyata terhadap berat segar krop, dimana perlakuan terbaik terdapat pada perlakuan pupuk kascing dan Herbafarm (K3H3) 1310,00 gram, namun tidak berbeda nyata dengan perlakuan (K3H2) yaitu 1273,33 gram, dan berbeda nyata dengan perlakuan lainnya. Hal ini disebabkan kombinasi perlakuan pupuk kascing sebanyak $1,8 \mathrm{~kg}$ plot dan herbafarm $75 \mathrm{ml}$ tanaman telah memenuhi unsur hara yang dibutuhkan tanaman dalam proses pertumbuhan.

Berat segar tanaman dipengaruhi oleh kadar air yang ada di dalam jaringan tanaman, terutama dengan mengikutsertakan air lebih dari $70 \%$ dari berat total air. Air membentuk ikatan hidrogen dengan bahan organik seperti protein dan karbohidrat. Hara yang diserap oleh akar diangkut bersama dengan air yang nantinya akan mempengaruhi berat tanaman (Lakitan, 2011).

Perlakuan K0H0 menunjuk- kan nilai berat buah segar yang sangat rendah. Hal ini disebabkan karena pada perlakuan K0H0 konsentrasi larutan hara yang dibutuhkan tanaman kurang sehingga mengakibatkan pertumbuhan tajuk yang kecil, ukuran daun yang kecil, tulang daun yang kecil sehingga krop menjadi kecil.

\section{Jumlah daun yang tidak membentuk krop (helai)}

Hasil pengamatan terhadap jumlah daun yang tidak membentuk krop, setelah dilakukan analisis ragam menunjukkan bahwa secara interaksi perlakuan antara pupuk kascing dan Herbafarm tidak memberikan pengaruh nyata terhadap jumlah daun yang tidak membentuk krop. Namun secara utama pupuk kascing dan Herbafarm memberikan pengaruh nyata terhadap jumlah daun yang tidak membentuk krop. Rerata jumlah daun yang tidak membentuk krop setelah di uji lanjut BNJ pada taraf 5\% dapat dilihat pada Tabel 4.

Berdasarkan Tabel 4 menunjukkan bahwa secara utama pengaruh pupuk kascing memberikan pengaruh nyata terhadap jumlah daun yang tidak membentuk krop, dimana perlakuan kascing sebanyak $1,8 \mathrm{~kg}$ per plot(K3) menghasilkan jumlah daun yang tidak membentuk krop lebih sedikit yaitu 9,00 helai daun namun berbeda nyata pada perlakuan lainnya. 
Tabel 4. Rerata jumlah daun yang tidak membentuk krop pada tanaman kubis dengan perlakuan kascing dan Herbafarm (helai)

\begin{tabular}{|c|c|c|c|c|c|}
\hline \multirow{2}{*}{ Dosis Kascing kg/plot } & \multicolumn{4}{|c|}{ Dosis Herbafarm ml per tanaman } & \multirow{2}{*}{ Rerata } \\
\hline & H0 (0) & H1 (25) & $\mathrm{H} 2(50)$ & H3 (75) & \\
\hline K0 (0) & 12,17 & 12,00 & 12,00 & 12,00 & $12,04 \mathrm{~b}$ \\
\hline K1 $(0,6)$ & 11,83 & 11,50 & 11,33 & 11,33 & $11,50 \mathrm{~b}$ \\
\hline $\mathrm{K} 2(1,2)$ & 11,17 & 11,17 & 11,17 & 10,67 & $11,04 \mathrm{~b}$ \\
\hline K3 $(1,8)$ & 10,33 & 9,83 & 8,50 & 7,33 & $9,00 \mathrm{a}$ \\
\hline Rerata & $11,37 \mathrm{~b}$ & $11,12 \mathrm{~b}$ & $10,75 \mathrm{~b}$ & $10,33 \mathrm{a}$ & \\
\hline
\end{tabular}

Angka-angka pada kolom dan baris yang sama yang diikuti oleh huruf yang sama tidak berbeda nyata menurut Uji lanjut BNJ pada taraf $5 \%$.

Lebih sedikitnya jumlah daun yang tidak membentuk krop disebabkan karena pemberian pupuk kascing dan Herbafarm, kedua pupuk tersebut merupakan pupuk organik sehingga hara yang terkandung lebih sedikit dibandingkan dengan pupuk anorganik, walaupun demikian pupuk organik telah memenuhi unsur hara makro dan mikro yang dibutuhkan oleh tanaman kubis. Sehingga semakin sedikit daun yang tidak membentuk krop maka semakin bagus karena daun tersebut telah membentuk krop.

\section{KESIMPULAN}

Interaksi pemberian pupuk kascing dan Herbafarm berpengaruh nyata terhadap diameter krop dan berat buah segar. Perlakuan terbaik pada pupuk kascing adalah $1,8 \mathrm{~kg}$ per plot dan herbafarm adalah $75 \mathrm{ml}$ per tanaman yaitu K3H3.

Pengaruh utama pemberian kascing nyata terhadap umur terbentuknya krop, diameter krop, berat segar krop dan jumlah daun yang tidak membentuk krop. Perlakuan terbaik kascing adalah $1,8 \mathrm{~kg}$ per plot yaitu K3.

Pengaruh utama pemberian Herbafarm nyata terhadap umur terbentuknya krop, diameter krop, berat segar krop dan jumlah daun yang tidak membentuk krop. Perlakuan terbaik herbafarm adalah $75 \mathrm{ml}$ per tanaman yaitu $\mathrm{H} 3$.

\section{DAFTAR PUSTAKA}

Badan Pusat Statistik (BPS) Indonesia. 2013. Ekspor. Berita resmi statistik. Jakarta.

Cahyono. 2005. Kubis bunga dan Brocolli. Kanisius, Yogyakarta.

Fransiska, S. 2009. Respon pertumbuhan dan produksi sawi terhadap penggunaan pupuk kascing dan pupuk organik cair.
Skripsi. Universitas Sumatera Utara.Medan.

Kariada, I. K. M. Sukadana, L. Kartini \& Y. Handayani. 2004. Laporan pengkajian pupuk organik kascing pada sayuran pinggiran perkotaan. IP2TP Denpasar.

Lakitan, B 2011. Dasar-dasar Fisiologi Tumbuhan. PT. Raja Grafindo Persada. Jakarta.

Lingga, P. dan Marsono. 2013. Petunjuk Penggunaan Pupuk. Edisi Revisi. Jakarta: Penebar Swadaya.

Mulat, T. 2003. Membuat dan manfaat kascing pupuk organik berkualitas. Agromedia Pustaka. Jakarta.

Musnawar, E.I. 2006. Pembuatan dan aplikasi pupuk organik padat. Seri Agro Tekno Penebar Swadaya. Cimanggis. Bogor.

Paramita, Eka. 2009. Pengaruh dosis kascing terhadap pertumbuhan dan hasil tanaman selada (Luctuca sativa).

Prawiranata, W. S. 2007. Dasar-dasar fisiologi tumbuhan I dan II Dept. Balai tumbuhan pertanian. Institut Pertanian Bogor

Sunarjono, H., dan Rismunandar. 2014. Kunci bercocok tanam sayur-sayuran penting di Indonesia. Jakarta: Penebar Swadaya. 240 hal.

Suriadikarta, Didi Ardi., Simanungkalit, R.D.M. 2006. Pupuk organik dan pupuk hayati. Jawa Barat: Balai Besar Penelitian dan Pengembangan Sumberdaya Lahan Pertanian. Hal 2. ISBN 978-979- 9474-57-5.

Syafrizal., R.I. 2014. Aktivitas enzim ligninolitik fungi pelapuk putih Omphalina sp. dan Pleorutus ostreatus pada limbah lignoselulosa. Skripsi Fakultas Pertanian. Bogor: Biokimia IPB. 
